\title{
MODERN INTEREST RATE POLICY AND THE PHENOMENON OF NEGATIVE INTEREST RATES
}

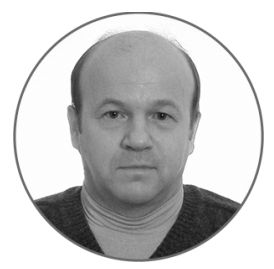

Article history:

Received 12 September 2016

Received in revised form

17 October 2016

Accepted 1 December 2016

Translated 26 November 2017

Available online 14 December 2017

JEL classification: E51, E52, E58

Keywords: interest rate policy, money mechanism, interest rate corridor, deflation, quantitative easing

\author{
Vladimir K. BURLACHKOV \\ Moscow State Institute of International Relations (University) \\ of Ministry of Foreign Affairs of Russian Federation, Moscow, Russian Federation \\ vkburl@gmail.com
}

\begin{abstract}
Importance The target interest rate is the main tool of the interest rate policy. Deflationary trends in leading economies undermined interest rates of central banks. It resulted in the phenomenon of negative interest rates on commercial banks' deposits.

Objectives The research focuses on the specifics of the modern interest rate policy of central banks in leading economies. I also identify what caused negative interest rates and outline a methodological framework for the interest rate policy in the Russian economy.

Methods The research is based on methods of logic and statistical analysis.

Results I unveil distinctions of central banks' interest rate policies, while the monetary mechanism of the modern economy evolves. I unfold the specifics of regulating interest rates with interest rate corridors. The article highlights distinctions in setting interest rates and the way they influence lending and liquidity. I also underpin the nexus between the formation of interest rates and leverage level of the economy. Interest rates were found to impact deflationary trends.

Conclusions and Relevance The specifics of the modern interest rate policies of central banks depends on the way the monetary mechanism evolves, i.e. the mechanism of the money supply. As central banks implemented payment systems, cash in correspondent accounts of commercial banks with central banks grew even more important. However, in targeting the rate on these reserves, central banks are constrained to influence interest rates on commercial bank's loans. That is why central banks are unable to effectively stimulate a growth in bank lending during the cyclical recession and have to apply an unconventional method to increase the money supply.
\end{abstract}

๑) Publishing house FINANCE and CREDIT, 2016

The editor-in-charge of this article was Irina M. Vechkanova

Authorized translation by Irina M. Vechkanova

Currently the financial and credit segments of leading countries demonstrate some common traits, such as a decline in deposit rates of central banks down to negative values, increase in public and private debts, higher leverage of the public sector and households.

\footnotetext{
${ }^{\dagger}$ For the source article, please refer to: Бурлачков B.К. Современная процентная политика центральных банков и феномен отрицательных процентных ставок. Финансы и кредит. 2016. № 47. С. 2-14.
}

The European Central Bank (ECB) set up the rate of negative 0.1 percent on overnight deposits of commercial banks and cut it down to negative 0.4 percent in March 2016. On January 29, 2016, the Bank of Japan pronounced its move to the policy of quantitative and qualitative easing and negative interest rates and imposed the rate of negative 0.1 percent on excess reserves of commercial banks. Central banks of Denmark and Sweden also introduced negative interest rates. 
These actions shall be viewed not only as an attempt to boost the economy, but also as a response to new trends in the formation of interest rates. As stated in proceedings by C. Borio [1], L. Rachel, T. Smith [2], G. Thwaites [3], developed countries have been experiencing a stable decline in yields on long-term government bonds and real policy rate, which is defined as the difference between the target short-term interest rate of the central bank and the inflation index.

The new trends left a trail in the way the monetary mechanism operates, i.e. the mechanism of money supply. As noted by the analysts of the Bank of England M. McLeay, M. Radia, R. Thomas, the money creation in fact differs from popular, though erroneous, concepts. That is, banks act as intermediaries and lend saving deposits, but, in the mean time, they do not multiply the central bank's money when they grant loans and accept deposits respectively. The amount of money created in the economy ultimately depends on the monetary policy of the central bank. Generally this policy is enforced through interest rates. The central bank can also influence the money supply by purchasing assets, i.e. quantitative easing [4].

According to the analysts of the U.S. Federal Reserve System S. Carpenter and S. Demiralp, the recent growth in bank reserves necessitates the revision of the nexus between banking reserves and money aggregates and bank lending. As they note, an analysis of the U.S. institutional structure and empirical data from the 1990s and onwards clearly shows that the transmission mechanism fails if based on the standard model of the money multiplier from reserves to money aggregates and bank loans [5].

As the contemporary practice of non-cash money creation proves, the mechanism of a money multiplier ceased to be actively used in the economic system, though being very current in the second half of the 20th century. The money multiplier concept is known to imply that money aggregates stem from the money base controlled by the central bank.

Issues of the money multiplier concept and its effect on interest rates were addressed in researches by U. Bindseil [6, 7], Z. Jakab and M. Kumhof [8]. $\mathrm{R}$. Werner providing empirical evidence of the non- cash money creation in the process of lending transactions and without reference to the money base $[9,10]$. Distinctions of the monetary policy in the contemporary environment were studied by A. Kashyap, J. Stein [11, 12], M. Farag, D. Harland, D. Nixon [13], C. Bowdler, A. Radia [14], L. Christiano and M. Eichenbaum [15]. The specifics of quantitative easing, as an unconventional lever of the money supply, was examined by J. Bridges, R. Thomas [16], S. Fullwiler, L. Wray [17], M.S. Mohanty [18], P. Mishra, P. Montiel [19], B. Fawley, C. Neely [20].

In my opinion, it is important to remember that current trends that arise in monetary segments of leading countries and result in dropping real and nominal interest rates have been evolving for many years. They originated from changes in the monetary mechanism of the contemporary economy, i.e. the money supply mechanism. It is the money supply growth that ensured the downward movement of interest rates.

The monetary mechanism of leading countries transformed due to a number of reasons. First, the prudential supervision of commercial banks was developed. It particularly refers to the adoption of the Basel I Accord (1988) and subsequent Basel II Accord. Second, payment systems of central banks were designed to streamline commercial banks' settlements. Those events took place in the early 1990s and led to unexpected implications.

As for the first implication, in the existing circumstances, the Basel capital adequacy ratio minimum requirement appeared to be a natural constraint on bank lending, rather than an inflow of deposits to a commercial bank. It enabled commercial banks to lend more, notwithstanding balances of accounts and their trends.

Assignment of previous loans to special purpose vehicles (SPV), subsequent securitization of those loans and sale of bonds in the financial market became another option for increased lending.

Upon the advent of central banks' payment systems, money circulating in such systems, i.e. balances of correspondent accounts (reserves), acquired special properties that distinguished them from bank deposits. It appeared that money in correspondent 
accounts (reserves) were not subject to a multiplicative effect and completely controlled by central banks. This is due to the fact that they are formed in the closed system, while money is debited from one correspondent account and credited to the other one simultaneously. Currently, the term banking sector liquidity is used denoting gross reserves of commercial banks at the central bank.

As the economists of the Bank of Norway T. Bernhardsen and A. Kloster point out, reserves of the central bank are the only generally accepted means of interbank settlements, with the central bank having the exclusive authority to create them. In the closed system, reserves of the central bank migrate throughout accounts of commercial banks at the central bank. Commercial banks cannot influence total reserves in the banking system, at their own discretion [21].

Thus, here we have a paradox. For purposes of lending transactions commercial banks got empowered to create the money supply limited only with the corporate sector and households' demand for loans. To create money, commercial banks may simply debit the Loans Granted account and credit the amount from the customer's account (borrower). Things get more complicated when the customer requests the bank to transfer money to the other bank. If there is not enough money in the correspondent account at the central bank, it shall be borrowed from the interbank market or central bank.

Currently, these features are common not only for the monetary mechanism of national economies, but also the mechanism for forming monetary liquidity in the global economy. Global currencies circulating in this sector are called European currency, according to the tradition dating back to the 1960s. The Eurodollar lays the basis for this. As S. Fowler emphasizes, Eurodollars, in a way, can be presented as decisions, rather than funds. Eurodollars are formed when aforeign banker assumes an obligation denominated in dollars as a deposit, notwithstanding that no cent will leave the U.S. Federal Reserve System [22].

Based on this example, the foreign (say, European) bank can place a dollar deposit, i.e. grant a loan to the customer, by making a banking entry through accounts of the balance sheet. However, if the customer requests to transfer the money to an U.S. bank, the bank that grants the loan and places the dollar deposit respectively shall raise a respective amount from the interbank market. Currently, commercial banks need the central banks' money to transfer money they created from one bank into another upon the customers' requests (borrowers), rather than to grant loans.

The monetary mechanism transformation, which caused an increase in the money supply and a drop in interest rates respectively, could but make many corporations and households seek loan refinance. It shaped the downward trend in interest rates. Unsustainability of money and credit aggregates was the first thing monetary regulators noticed in the early 2000s when the situation changed. It derogated the targeting of monetary indicators and paved the way for the regulation of interest rates. It is noteworthy that various countries made attempts to manage interest rates. However, such regulatory attempts were not very efficient, impeding any prompt reaction to economic activities and price dynamics.

In the early 2000s, leading countries were setting up their practices for regulating interest rates, while the formation of the latter underwent significant changes. As the money mechanism evolved, the short-term interest rate, which central banks control, turned into a tariff for transporting money from one commercial bank into the other one through their correspondent accounts at the central bank.

As part of their interest rate policy, the U.S. Federal Reserve System sets the target rate on federal funds. This interest rate is overnight. Banks with excess statutory reserves grant loans to banks with insufficient statutory reserves. The target rate of the Federal Reserve System on federal funds is the critical metric of excess statutory reserves. The effective federal funds rate is the weighted average rate of market deals commercial banks make with federal funds, i.e. lending transactions based on federal funds.

In addition to the target rate on federal funds, the interest rate on required reserves - IORR and 
the interest on excess reserves rate - IOER are used in the USA.

IORR is paid on statutory reserves, which the U.S. banks are bound to hold in the Federal Reserve System. IOER is charged on the amount of factual reserves (that is, commercial banks' funds in accounts at the Federal Reserve System) that exceeds statutory reserves. IOER and interests charged on excess reserves in particular are tools the Federal Reserve System resorts to absorb excess liquidity. They resemble the European Central Bank's practice of attracting excess resources into deposits.

As part of its interest rate policy, the ECB maintains an interest rate corridor. The ceiling of the interest rate corridor is the marginal lending facility rate. Using this rate, the ECB injects liquidity into the banking sector in case the overnight interest rate of the monetary market increases.

The floor of the interest rate corridor is the overnight deposit facility rate. Using this rate, the ECB shall raise excess liquidity for deposits in ordinary circumstances. Adhering to the quantitative easing policy, the ECB sets up a negative interest rate on deposits of 0.4 percent so as to urge commercial banks to utilize their reserves.

In addition to the above rates, the ECB applies the main refinancing rate. The ECB applies it when making weekly transactions for providing additional liquidity to the banking sector.

When implementing its interest rate policy, the Bank of England sets up the target overnight interest rate. The Bank of England absorbs excess liquidity attracting deposits at the deposit rate. If liquidity is insufficient and the short-term interest rate increases respectively, the Bank of England provides the banking system with additional reserves at the lending rate. Thus, the Bank of England maintains the bank rate within the corridor bounds. The lending rate is its ceiling, and the deposit rate is its floor. Central banks set up a symmetric corridor of its fluctuations. The identical model is run in Russia through the key rate.

When using the interest rate corridor, central banks of leading countries both ensure the supply of monetary liquidity (in case the target interest rate hits its ceiling) and absorb the excess liquidity by streaming it to deposits (in case the target interest rate hits its floor). These measures draw the interbank interest rate into the middle of the corridor.

To forecast the trajectory of the target interest rate within the corridor, central banks shall consider how autonomous factors (the banking system's demand for cash and transactions of the governmental treasury) change. As part of these transactions, treasuries gain proceeds and incur expenses [6].

Initially, interest corridors were put in practice by the ECB and central banks of Australia, Canada, New Zealand [6]. It is worth mentioning that only one in four (ECB) central banks employs the system of statutory reserves. From their inception, interests rates are regarded as a versatile tool to regulate monetary liquidity central banks provide. In the USA the excess liquidity of the banking system is not pooled into deposits. Interests are paid on such liquidity. This practice led to an important consequence. Excess statutory reserves turned into a type of risk-free assets.

As the monetary mechanism evolves, the conversion of (1) bank deposits and (2) balances of correspondent accounts into two separate elements shaped the specifics of interests rates in the contemporary economy. They are involved in the regulation of the interest rate on reserves, i.e. the central bank's money. Commercial banks request this money for transferring customers' deposits, i.e. money they create when they lend. If commercial banks need more resources than the central bank can give, the latter has to create more money (reserves) in maintaining the interest rate within the given corridor. It means that the interest rate corridor is de facto a tool to correlate the central bank's money supply and the amount of money generated by commercial banks. However, this mechanism actually results in refinancing of the economy and a drop in interest rates.

As proved in practice, the interest rate corridor poses a substantial threat to countries, the currencies of which depend on resources. For example, Russia. If the global price for goods, which such countries export, drops, national currency markets become turbulent. Under these circumstances, commercial banks transfer their 
funds through the central bank's payment system to a stock exchange. Those funds are money generated by commercial banks indeed. Maintaining the target interest rate within the given corridor, the central bank increases the volume of liquidity. That is, it issues reserves as a special element of the money supply. In this case, speculation against the national currency can be beaten if the target rate (the key rate in Russia) is increased so much as to make speculative transactions with currency less profitable for commercial banks. As seen in the market, a spiking increase in the key interest rate disrupts lending processes in the national economy.

Targeting the federal funds rate (FFR) is a distinction of the U.S. Federal Reserve System's interest rate policy. As federal funds needed to be raised on an interest-rate basis to settle customers' accounts, the U.S. commercial banks could but try diminishing the demand for such funds. To address the issue, commercial banks chose to transfer balances of customers' accounts from deposit account to the currency market since they are exempt from reserve requirements. Private netting offices became another option to reduce commercial banks' demand for federal funds. CHIPS (Clearing House and Interbank Payment System) processes multiple clearing transactions among the U.S. banks, and Fedwire finalizes the settlements. Smaller banks choose to make payments through local systems. Transactions with securities are settled via DTCC (Depositary Trust and Clearing Corp.) and FICC (Fixed Income Clearing Corp.). To become less dependent on federal funds, the U.S. banks started to raise resources from the Eurodollar market and perform REPO transactions. Such operations had a tremendous effect. They intensified the effect of the federal funds rate on short-term interest rates, which are formed in other markets and the markets of Eurodollars and REPO in particular. Those markets started arbitrage trading.

As netting mechanisms evolve, the U.S. banking system needs much less federal funds, and banks attract fewer overnight loans for their payment purposes. However, as the amount of reserve funds decreased, FFR became more volatile. Insufficient funds for payments cause the volatility of this rate in certain periods of time.
As netting practices expand, federal funds will become less important for the monetary policy of the Federal Reserve System. Hence, it is noteworthy that some countries (Australia and Canada in particular) adopted legislative remedies for using solely central banks' money in order to finally settle payments in the banking system. As per laws of the countries, it is money of central banks that ensures the final settlement among commercial banks [23].

The monetary mechanism and its evolution dictated the way interest rates are formed in line with the special role of such elements of the money supply as bank deposits and reserves (balances of correspondent accounts). In the contemporary economy corporate and household lending is based on endogenous (internal) money generated by commercial banks. In this type of lending, interest rates depend on the demand for credit resources and banks' lending capabilities in accordance with principles of prudential supervision and credit risks of specific classes of borrowers. To transfer customers' funds, including those ones from a lending transaction, in the payment system of the central bank, commercial banks use exogenous (external) money generated by monetary authorities in ensuring the banking sector's liquidity. So, it is money that commercial banks hold at the central bank. The interest rate on respective loans is set by central banks.

Therefore, commercial banks grant loans to customers at the interest rate on endogenous money created by commercial banks. The interest rate which the central bank maintains within the corridor is the rate on exogenous money created by central banks. As I have already mentioned, this interest rate virtually constitutes the tariff for remitting money from one bank to the other.

The interest rate which central banks target at has no direct impact on the amount of loans commercial banks provide to the real economy and households. However, it determines whether commercial banks are capable of making timely remittances via the payment system upon customers' requests.

The rate on reserves can influence the situation in the financial market, being a kind of an anchor since the interest rate policy of central banks fails to 
stipulate any quantitative benchmarks. For instance, this rate has an impact on yields on government bonds.

It is important to note, for purposes of maintaining the interest rate within the given corridor, deposit accounts of commercial banks at the central bank hold money that ensures the remittance from one bank to the other one during payments. That is why lending activity cannot be stimulated by imposing the negative interest rate on respective deposits.

The interest rate policy of central banks has become less influential in forming interest rates on bank loans issued to companies and households for the recent decades after the said changes in the monetary mechanism. The interest policy of monetary authorities became less effective. The problem is that the interest rate on reserves as set by central banks can exert a certain pressure on lending activities of commercial banks, which currently depend on the capital-to-asset ratio. It restricted the impact central banks could have on the aggregate demand and price dynamics. Thus, regulating the interest rate on reserves (the key rate in Russia), which is very common in the contemporary economy, cannot be considered as an effective tool of inflation targeting.

The low interest rate is often called the liquidity trap. The term originates in the Keynesian theory of the demand for money to describe distinguishing features of the situation that arises at the cyclical depression phase, i.e. when the aggregate demand and deflationary trends fall. However, this situation does not last for a long time. In the contemporary economy too low interest rates can have other roots. These are changes in the monetary mechanism after central banks introduce their payment systems and the Basel capital adequacy ratio is introduced, which actually blazed the money supply.

Hence, as a result of the monetary mechanism evolution, the short-term interest rate, which central banks target at, has a limited effect on lending activities of commercial banks. This is due to the fact that commercial banks utilize reserves subject to the said interest rate to remit money within the closed payment system of the central bank upon customers' requests (borrowers), rather than to provide loan to companies and households.

Considering the existing monetary mechanism, the short-term interest rate on monetary liquidity, which circulates in the payment system of central banks, will not guarantee the efficiency of the monetary policy aimed to support the economic growth and ensure the relative stability of price indicators.

This is no coincidence resulting from the unconventional monetary policy, interest rates which monetary authorities of developed economies target at approximate zero and the rates on credit institutions' deposits at central banks become negative. They consistently stem from the monetary mechanism transformation, being influenced by the evolution of the governmental regulation and a response of market forces to regulatory measures. The monetary mechanism was modified so to emphasize the special role commercial banks' reserves (balances of correspondent accounts) play to finalize interbank settlements in the closed payment system of the central bank (the adoption of the Basel Accord). The changes also concerned lending activities of commercial banks in line with the capital-to-assets ratio.

The changes boosted the money supply in leading economies and made the corporate sector and households have their loans refinanced. Subsequent attempts to optimize the debt burden engendered deflationary trends. Longstanding deleveraging is the only way to overwhelm the trends. Besides, central banks should configure their policies so as to cease regulating interest rates and manage credit aggregates comprehensively.

\section{Acknowledgments}

I express my gratitude and deep appreciation to Sergei A. ANDRYUSHIN, Doctor of Economics, Chief Research Associate of the Institute of Economics of the Russian Academy of Sciences, for his valuable advice and comments on the article. 


\section{References}

1. Borio C. Revisiting Three Intellectual Pillars of Monetary Policy Received Wisdom. URL: http://www.bis.org/speeches/sp151112.pdf

2. Rachel L., Smith T. Secular Drivers of the Global Real Interest Rate. Bank of England Staff Working Paper, 2015, no. 571. URL: http://www.centreformacroeconomics.ac.uk/Discussion-Papers/2016/CFMDP201605-Paper.pdf

3. Thwaites G. Why are Real Interest Rates So Low? Secular Stagnation and the Relative Price of Investment Goods. Bank of England Staff Working Paper, 2015, no. 564.

URL: http://www.bankofengland.co.uk/research/Documents/workingpapers/2015/swp564.pdf

4. McLeay M., Radia A., Thomas R. Money Creation in the Modern Economy.

Bank of England Quarterly Bulletin, 2014, Q1.

URL: http://www.bankofengland.co.uk/publications/Documents/quarterlybulletin/2014/qb14q101.pdf

5. Carpenter S., Demiralp S. Money, Reserves and the Transmission of Monetary

Policy: Does the Money Multiplier Exist?

URL: https://www.federalreserve.gov/pubs/feds/2010/201041/201041 pap.pdf

6. Bindseil U. Monetary Policy Operations and the Financial System. Oxford, Oxford University Press, 2014, $320 \mathrm{p}$.

7. Bindseil U. The Operational Target of Monetary Policy and the Rise and Fall of the Reserve Position Doctrine. ECB Working Paper Series, 2004, no. 372, 44 p.

URL: https://www.ecb.europa.eu/pub/pdf/scpwps/ecbwp372.pdf?45b110aa94d14117d8ed98277c4d55a4

8. Jakab Z., Kumhof M. Banks are not Intermediaries of Loanable Funds - and Why This Matters.

URL: http://voxeu.org/article/banks-are-not-loanable-funds-intermediaries-macroeconomic-implications

9. Werner R. Can Banks Individually Create Money Out of Nothing? - The Theories and the Empirical Evidence. International Review of Financial Analysis, 2014, vol. 36, pp. 1-19.

URL: https://doi.org/10.1016/j.irfa.2014.07.015

10. Werner R. How do Banks Create Money, and Why Can Other Firms not Do the Same? An Explanation for the Coexistence of Lending and Deposit-taking. International Review of Financial Analysis, 2014, vol. 36, pp. 71-77. URL: https://doi.org/10.1016/j.irfa.2014.10.013

11. Kashyap A., Stein J. The Impact of Monetary Policy on Bank Balance Sheets. Carnegie-Rochester Conference Series on Public Policy, 1995, no. 42, pp. 151-195.

12. Kashyap A., Stein J. What Do a Million Observations on Banks Say about the Transmission of Monetary Policy. The American Economic Review, 2000, vol. 90, no. 3, pp. 407-428.

13. Farag M., Harland D., Nixon D. Bank Capital and Liquidity. Bank of England Quarterly Bulletin, 2013, vol. 53, iss. 3, pp. 201-215.

14. Bowdler C., Radia A. Unconventional Monetary Policy: The Assessment. Oxford Review of Economic Policy, 2012, vol. 28, no. 4, pp. 603-621. URL: https://doi.org/10.1093/oxrep/grs037

15. Christiano L., Eichenbaum M., Evans C. Monetary Policy Shocks: What Have We Learned and to What End? NBER Working Paper, 1998, no. 6400, 95 p.

16. Bridges J., Thomas R. The Impact of QE on the UK Economy: Some Supportive Monetarist Arithmetic. Bank of England Working Paper, 2012, no. 442, 52 p.

URL: http://www.bankofengland.co.uk/research/Documents/workingpapers/2012/wp442.pdf 
17. Fullwiler S., Wray L. Quantitative Easing and Proposals for Reform of Monetary Policy Operations. Levy Economic Institute Working Paper, 2010, no. 645, 35 p. URL: http://www.levyinstitute.org/pubs/wp_645.pdf

18. Mohanty M.S. The Transmission of Unconventional Monetary Policy to the Emerging Markets: An Overview. BIS Papers, 2014, no. 78, 24 p. URL: http://www.bis.org/publ/bppdf/bispap78.htm

19. Mishra P., Montiel P. How Effective is Monetary Transmission in Low-Income Countries? A Survey of the Empirical Evidence. IMF Working Paper, 2012, no. WP/12/143, 47 p. URL: https://www.imf.org/external/pubs/ft/wp/2012/wp12143.pdf

20. Fawley B., Neely C. Four Stories of Quantitative Easing. Federal Reserve Bank of St. Louis Review, 2013, vol. 95, iss. 1, pp. 51-88.

21. Bernhardsen T., Kloster A. Misunderstood Central Bank Reserves. Norges Bank Economic Commentaries, 2012, no. 1. URL: http://www.norges-bank.no/pages/87889/Economic_Commentaries_2012_1.pdf

22. Fowler S. The Monetary Fifth Column: The Eurodollar Threat to Financial Stability and Economic Sovereignty. Vanderbilt Journal of Transnational Law, 2014, vol. 47, pp. 825-860.

23. Fullwiler S. Setting Interest Rates in the Modern Money Area. Journal of Post Keynesian Economics, 2006, vol. 28, no. 3, pp. 496-525.

\section{Conflict-of-interest notification}

I, the author of this article, bindingly and explicitly declare of the partial and total lack of actual or potential conflict of interest with any other third party whatsoever, which may arise as a result of the publication of this article. This statement relates to the study, data collection and interpretation, writing and preparation of the article, and the decision to submit the manuscript for publication. 